\title{
HUMAN TYPE II COLLAGEN GENE (COL2A1) ASSIGNED TO CHROMOSOME 12q13.1-q13.2 BY IN SITU HYBRIDIZATION WITH BIOTINYLATED DNA PROBE
}

\author{
Ei-ichi TAKahaShI, ${ }^{1}$ Tada-aki HorI, ${ }^{1}$ Jeanne B. LAWrence, ${ }^{2}$ \\ John MCNeIL, ${ }^{2}$ Robert H. Singer, ${ }^{2}$ Peter O'ConNell, ${ }^{3}$ \\ Mark LEPPERT, ${ }^{3}$ and Ray WHITE ${ }^{3}$ \\ ${ }^{1}$ Division of Genetics, National Institute of Radiological Sciences, \\ Anagawa, Chiba 260, Japan \\ ${ }^{2}$ Department of Cell Biology, University of Massachusetts Medical School, \\ 55 Lake Avenue, North Worcester, Massachusetts 01655, U.S.A. \\ ${ }^{3}$ Howard Hughes Medical Institute, University of Utah Medical Center, \\ 603 Wintrobe Building, Salt Lake City, Utah 84132, U.S.A.
}

\begin{abstract}
Summary We have made a regional assignment of the type II collagen gene (COL2A1) on human chromosome 12 by means of an in situ hybridization technique with a biotinylated DNA probe. The precise localization of the signal was mapped to the band 12q13.1-q13.2. This result was in agreement with the previous mapping by isotopic in situ hybridization technique (12q13.1-q13.2), but not with the result of Southern hybridization analysis using somatic cell hybrids (12q14.3).

Key Words nonisotopic in situ hybridization, chromosome mapping, COL2A1 and chromosome 12
\end{abstract}

\section{INTRODUCTION}

The use of in situ hybridization has made it possible to localize specific DNA sequences directly on metaphase chromosomes. The techniques using isotopic DNA probes have, however, had some disadvantages to be overcome. Recently, many investigators have made great efforts to develop the techniques with nonisotopic biotinylated DNA probes (Langer et al., 1981; Manuelidis et al., 1982; Pinkel et al., 1986; Moyzis et al., 1987; Lawrence et al., 1988; Cherif et al., 1989). They are based on chemically modified DNA probes and on immunologic reaction for the detection.

The human type II collagen gene (COL2A1) has been assigned to chromosome 12 (Strom et al., 1984; Solomon et al., 1985). However, there has been some dis-

Received November 21, 1989; Accepted December 11, 1989. 
crepancy in the precise localization, that is, 12q14.3 mapped by Southern hybridization analysis (Law et al., 1986) and 12q13.1-q13.2 by isotopic in situ hybridization (Huerre-Jeanpierre et al., 1986). According to the report of the committee on genetic constitution of chromosomes 12 and 13 in Tenth International Workshop on Human Gene Mapping (Ropers and Craig, 1989), the COL-2A1 gene has been assigned to $12 \mathrm{q} 14.3$.

In the present communication, we report the regional assignment of the human type II collagen gene (COL2A1) to human chromosomes by means of a previously described in situ hybridization procedure using biotinylated DNA probe, which is demonstrated to be capable of localizing single copy sequences with high resolution (Lawrence et al., 1988).

\section{MATERIALS AND METHODS}

Chromosome preparation and G-banding. The metaphase chromosome spreads were prepared from PHA-stimulated peripheral lymphocytes of a healthy male donor by a standard method. Trypsin G-bandings were applied for detailed analysis of the position of signals prior to hybridization. The chromosome slides were kept at $65^{\circ} \mathrm{C}$ for $3 \mathrm{hr}$ for hardening of chromosome materials (Lawrence et al., 1988).

DNA probe. A cosmid clone for the human type II collagen gene (COL2A1), designated cosHcol2A (Cheah et al., 1985), was used in the present study. This cosmid clone contains a $36 \mathrm{~kb}$ insert.

Probe labeling. The DNA probe was labeled by enzymatic incorporation of biotin 7-dATP (Bethesda Research Laboratories, BRL, U.S.A.) by the nick translation technique according to the manufacturer's direction (BRL). The biotinylated DNA fragments were denatured for $10 \mathrm{~min}$ at $75^{\circ} \mathrm{C}$ in $100 \%$ formamide, after purification by an ethanol precipitation method using sonicated salmon sperm DNA. The probe concentration was $100 \mathrm{ng}$ per slide in the present study.

Chromosome denaturation. Chromosomes were denatured in $70 \%$ formamide$2 \times \mathrm{SSC}$ at $70^{\circ} \mathrm{C}$ for $2 \mathrm{~min}$, following ethanol-dehydration $(70 \%$ and $100 \%, 5 \mathrm{~min}$ each, Lawrence et al., 1988).

Hybridization and rinsing. In situ hybridization and rinsing were performed by the method of Lawrence et al. $(1988,1989)$. The hybridization solution consisted of bovine serum albumin (BSA) $(20 \mathrm{mg} / \mathrm{ml}$, Boehringer), $20 \times \mathrm{SSC}, 50 \%$ dextran sulfate and $0.1 \mathrm{M} \mathrm{NaPO}_{4}(1: 1: 2: 1)$. The hybridization solution was mixed with an equal volume of the denatured probe in formamide. The mixture was pipetted onto the denatured chromosome slides, covered with parafilm and incubated in a humid chamber at $37^{\circ} \mathrm{C}$ overnight. The slides were rinsed for $30 \mathrm{~min}$ each in $50 \%$ formamide $-2 \times \mathrm{SSC}$ at $37^{\circ} \mathrm{C}, 2 \times \mathrm{SSC}$ and finally $1 \times \mathrm{SSC}$ at room temperature.

Detection. The slides were then incubated in $3 \mu \mathrm{g} / \mathrm{ml}$ fluorescein avidin (Boehringer) in $4 \times \mathrm{SSC}$ with $1 \% \mathrm{BSA}$ (Sigma) at $37^{\circ} \mathrm{C}$ in a humid chamber. After $45 \mathrm{~min}$, 
they were rinsed in $4 \times \mathrm{SSC}, 4 \times \mathrm{SSC}$ with $0.1 \%$ Triton $\mathrm{X}$ and $4 \times \mathrm{SSC}$ for $10 \mathrm{~min}$ each on a shaker at room temperature (Lawrence et al., 1988). They were counterstained with the DNA fluorochrome, propidium iodide $(1.25 \mu \mathrm{g} / \mathrm{ml}$, Sigma) in antibleach mounting medium ( $1 \%$ diazabicyclooctane, Sigma, in glycerol with $10 \%$ PBS, Lawrence et al., 1989). We used Nikon Microphoto-FX with epifluorescence optics for propidium iodide and for fluorescein avidin (filter combinations, Nikon G-2A and B-2E). Photographs were taken by Kodak Tri-X film (ASA 400).

\section{RESULTS AND DISCUSSION}

Of 100 metaphase plates examined, $86(86 \%)$ had specific signals as two symmetrical spots on the sister chromatids of both homologues of chromosome 12 (Fig. 1, A and B). No such double spots were observed on other chromosomes. G-banding patterns of the same metaphases indicated that the signals were placed at the proximal part of the long arm of chromosome 12 (Fig. 1, C-F). The precise localization of COL2A1 could be assigned to the band 12q13.1-q13.2.

According to the result of Law et al. (1986), the COL2A1 gene was mapped to the band $12 \mathrm{q} 14.3$ by the Southern hybridization analysis of DNA from a panel

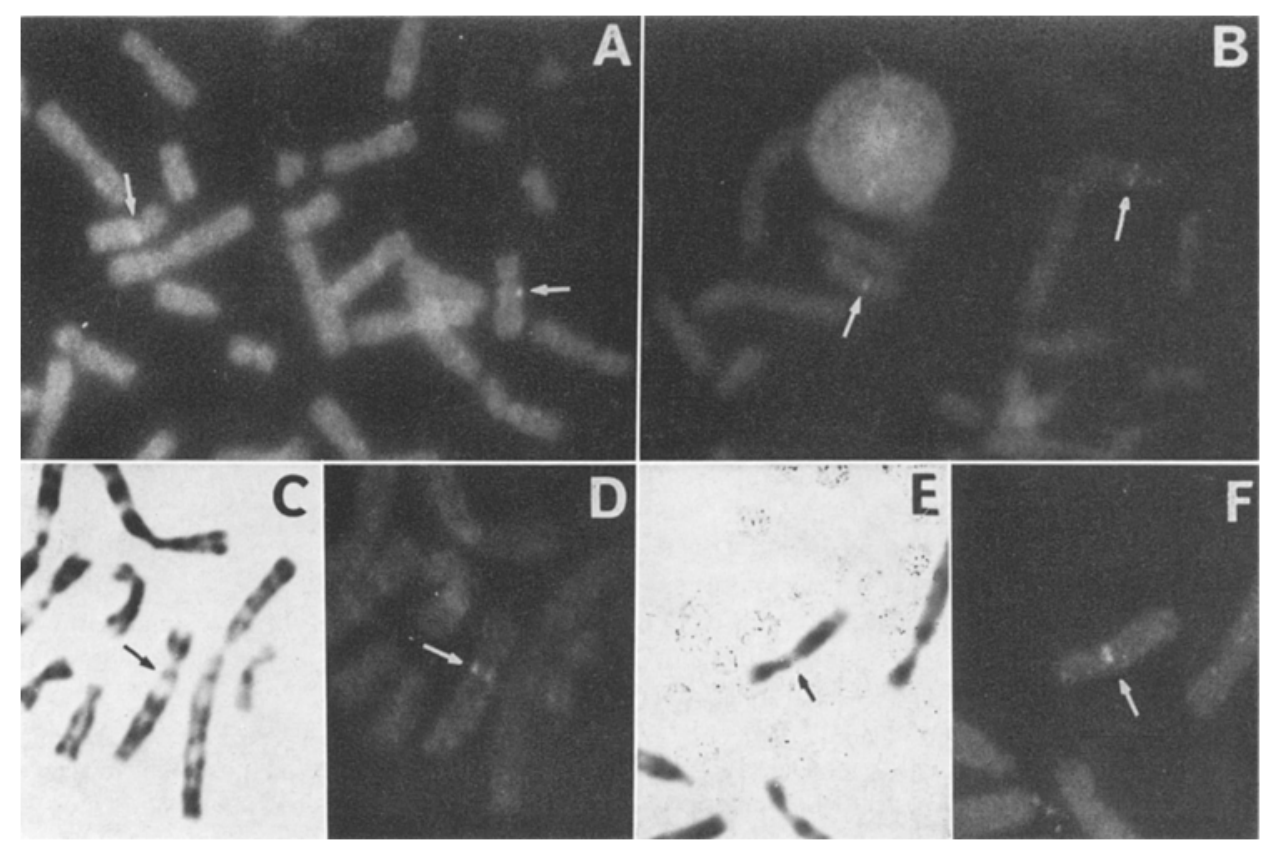

Fig. 1. A and B: Two partial metaphases with chromosome 12 homologues hybridized by biotinylated COL2A1. C, D, E and F: Chromosome 12 hybridized (right) on the same plates of G-banding (left), respectively. Arrows indicate the signals on chromosome 12q13.1-q13.2 and their G-bandings. 
of human-hamster somatic cell hybrids containing various portions of human chromosome 12. On the other hand, Huerre-Jeanpierre et al. (1986), using isotopic in situ hybridization to metaphase chromosomes of human lymphoblastic cells, have reported that the localization was to the band 12q13.1-q13.2. Our result was in agreement with Huerre-Jeanpierre's report.

A fragile site may be useful as a landmark for gene mapping. In this region of chromosome 12, a rare type of folate sensitive fragile site, FRA12A, fra(12)(q13.1), has been mapped (Sutherland and Mattei, 1987). Use of this site may allow more precise mapping of COL2A1 in the future.

It has been known that inherited connective tissue disorders are associated with defects in collagen metabolism. Specific defects at molecular level and their phenotypic consequences have been shown in families with such inherited disorders. Restriction fragment length polymorphisms (RFLPs) have been identified within the coding region of COL2A1 (Väisänen et al., 1988). Palotie et al. (1989) have reported a close linkage of COL2A1 to familial osteoarthrosis. Additional linkage evidence for involvement of a locus close to or identical with COL2A1 has been provided by the studies on a progressive, generalized osteoarthritis (Knowlton et al., 1989). More recently, Lee et al. (1989) have also reported an association of spondyloepiphyseal dysplasia (SED) with COL2A1 defects by detecting heterozygosity for a deletion of this gene in affected members of an SED family. Physical mapping of COL2A1 can generate new insights into analyzing the molecular defects of such genetic disorders.

Acknowledgments We are indebted to L. Rowe for expert technical assistance. This work was financially supported by a Grant-in-Aid of Lateral International Joint Research of Special Coordination Funds for Promoting Science and Technology, Science and Technology Agency, Japan.

\section{REFERENCES}

Cheah, K.S.E., Stoker, N.G., Griffin, J.R., Grosveld, F.G. and Solomon, E. 1985. Identification and characterization of the human type II collagen gene (COL2A1). Proc. Natl. Acad. Sci. U.S.A. 82: 2555-2559.

Cherif, D., Bernard, O. and Berger, R. 1989. Detection of single-copy genes by nonisotopic in situ hybridization on human chromosomes. Hum. Genet. 81: 358-362.

Huerre-Jeanpierre, C., Mattei, M.G., Weil, D., Grzeschik, K.H., Chu, M.L., Sangiorgi, F.O., Sobel, M.E., Ramirez, F. and Junien, C. 1986. Further evidence for the dispersion of the human fibrillar collagen genes. Am. J. Hum. Genet. 38: 26-37.

Knowlton, R.G., Katzenstein, P., Moskowitz, R.W., Weaver, E.J., Jimenez, S.A., Pathria, M.N., Malmud, C.J. and Prockop, D.J. 1989. Genetic linkage of the type II procollagen gene to primary generalized osteoarthritis with chondrodysplasia (10th International Workshop on Human Gene Mapping), Cytogenet. Cell Genet. 51: 1024.

Langer, P.R., Waldrop, A.A. and Ward, D.C. 1981. Enzymatic synthesis of biotin-labeled polynucleotides: Novel nucleic acid affinity probes. Proc. Natl. Acad. Sci. U.S.A. 78: 6633-6637.

Law. M.L., Tung, I., Morse, H.G., Berger, R., Jones, C., Cheah, K.S.E. and Solomon, E. 1986. The human type II collagen gene (COL2A1) assigned to 12q14.3. Ann. Hum. Genet. 50: 
131-137.

Lawrence, J.B., Villnave, C.A. and Singer, R.H. 1988. Sensitive, high-resolution chromatin and chromosome mapping in situ: Presence and orientation of two closely integrated copies of EBV in a lymphoma line. Cell 52: 51-61.

Lawrence, J.B., Singer, R.H. and McNeil, J. 1989. High-resolution gene mapping at interphase and metaphase: Visual resolution of sequences at different distances within the dystrophin gene. Science (in press).

Lee, B., Vissing, H., Ramirez, F., Rogers, D. and Rimoin, D. 1989. Identification of the molecular defect in a family with spondyloepiphyseal dysplasia. Science 244: 978-980.

Manuelidis, L., Langer-Safer, P.R. and Ward, D.C. 1982. High-resolution mapping of satellite DNA using biotin-labeled DNA probes. J. Cell Biol. 95: 619-625.

Moyzis, R.K., Albright, K.L., Bartholdi, M.F., Cram, L.S., Deaven, L.L., Hildebrand, C.E., Joste, N.F., Longmire, J.L., Meyne, J. and Schwatzacher-Robinson, T. 1987. Human chromosomespecific repetitive DNA sequences: Novel markers for genetic analysis. Chromosoma 95: 375-386.

Palotie, A., Väisänen, P., Otto, J., Ryhänen, L., Elima, K., Vikkula, M., Cheah, K., Vuorio, E. and Peltonen, L. 1989. Predisposition of familial osteoarthrosis linked to type II collagen gene. Lancet 1: 924-927.

Pinkel, D., Straume, T. and Gray, J.W. 1986. Cytogenetic analysis using quantitative, high sensitivity, fluorescence hybridization. Proc. Natl. Acad. Sci. U.S.A. 83: 2934-2938.

Ropers, H.H. and Craig, I.W. 1989. Report of the committee on the genetic constitution of chromosomes 12 and 13 (Tenth International Workshop on Human Gene Mapping). Cytogenet. collagen: Cell Genet. 51: 259-279.

Solomon, E., Hiorns, L.R., Spurr, N., Kurkinen, M., Barlow, D., Hogan, B.L.M. and Dalgleish, R. 1985. Chromosomal assignments of the genes coding for human types II, III and IV A dispersed gene family. Proc. Natl. Acad. Sci. U.S.A. 82: 3330-3334.

Strom, C.M., Eddy, R.L. and Shaws, T.B. 1984. Localization of human type II procollagen gene (COL2A1) to chromosome 12. Somat. Cell Mol. Genet. 10: 651-655.

Sutherland, G.R. and Mattei, J.F. 1987. Report of the committee on cytogenetic markers (9th International Workshop on Human Gene Mapping). Cytogenet. Cell Genet. 46: 316-324.

Väisänen, P., Elima, K., Palotie, A., Peltonen, L. and Vuorio, E. 1988. Polymorphic restriction sites of type II collagen gene: Their location and frequencies in the Finnish population. Hum. Hered. 36: 65-71. 